\title{
URGENSI PENGATURAN PERBUKUAN NASIONAL
}

\section{B.P. Sitepu}

\begin{abstract}
Printed materials such as books are still used as the main resources in instructional process in formal and non-formal education. Books are also used to disseminate many kinds of information for various purposes. The intellectual advancement of a nation can be measured from its book industry development. The book industry in Indonesia has a low product and can not compete against other countries even in the Southeast Asia. It faces a lot of obstacles in the aspects of manuscript provision, printing, publishing, distributing, and marketing. This article discusses the urgent need of book regulations to develop book industry in Indonesia. It believes that the appropriate book regulations followed by law enforcement will be able to stimulate the book industry development in Indonesia. Many problems concerning the authorship, publishing, printing, distribution, and marketing can be solved with national book regulations.
\end{abstract}

Key words: book industry, authorship, printing, publishing, distribution, marketing, book regulations.

\begin{abstract}
Abstrak
Bahan cetakan seperti buku masih dipergunakan sebagai sumber utama dalam proses pembelajaran formal dan nonformal. Buku juga dipergunakan dalam menyebarluaskan berbagai jenis informasi dengan aneka tujuan. Kemajuan intelektual suatu bangsa dapat diukur dari kemampuan industri perbukuannya. Industri buku di Indonesia mempunyai produksi yang rendah dan tidak mampu bersaing dengan negaranegara lain walaupun di Asia Tenggara. Terdapat berbagai hambatan dalam perolehan naskah, percetakan, penerbitan, penyaluran, dan pemasaran. Tulisan berikut ini mendeskripsikan pentingnya regulasi untuk mengembangkan industri buku di Indonesia. Diyakini bahwa regulasi buku yang tepat disertai dengan penerapan hukum yang konsisten dapat mendorong perkembangan industri buku di Indonesia. Disimpulkan banyak masalah dalam kepengarangan, penerbitan, percetakan, penyaluran, dan pemasaran dapat dipecahkan melalui regulasi perbukuan nasional.
\end{abstract}

Kata kunci: industri buku, kepengarangan, percetakan, penerbitan, penyaluran, pemasaran, regulasi buku.

\section{DASAR PIKIRAN}

Salah satu tujuan kemerdekaan Republik Indonesia sebagaimana disebutkan dalam Pembukaan UUD Tahun 1945 ialah mencerdaskan kehidupan bangsa sehingga dapat hidup setara dengan bangsabangsa maju lainnya. Tujuan itu akan dicapai melalui pendidikan dalam arti yang luas, pendidikan dalam keluarga, masyarakat, dan lembaga-lembaga pendidikan formal dan nonformal. Melalui proses pendidikan sepanjang hayat diwujudkan manusia Indonesia seutuhnya yang memiliki kepribadian dengan kecerdasan intelektual, spiritual, dan sosial yang seimbang. Melalui proses pendidikan yang demikian maka setiap insan Indonesia akan dapat mengembangkan diri dan lingkungannya sehingga memiliki kualitas hidup yang lebih baik serta mampu berkolaborasi dan bersaing dengan bangsa lain. Proses pendidikan yang mencerdaskan dan bermartabat memerlukan aneka sumber- sumber belajar yang salah satunya adalah buku.

Adalah juga menjadi cita-cita bangsa dan negara Indonesia mewujudkan masyarakat yang adil dan makmur serta berakhlak mulia secara merata yang merupakan jati diri bangsa yang maju dan beradab. Salah satu cara untuk mewujudkan bangsa yang sejahtera, maju, dan berkeadilan adalah melalui pembentukan masyarakat terdidik (educated society) dan bermartabat yang gemar belajar (learning society) serta memiliki budaya gemar membaca di dalam berbagai aspek kehidupannya (reading society). Masyarakat yang adil dan makmur adalah masyarakat terdidik karena gemar belajar dari berbagai sumber informasi yang antara lain dalam bentuk bahan bacaan yang memadai dilihat dari jenis, jumlah, mutu, serta kemudahan memperolehnya.

Buku sebagai salah satu media informasi tertua dan konvensional, masih tetap dibutuhkan walaupun dewasa ini media elektronik berkembang pesat dan maju sebagai perwujudan dari kemajuan teknologi 
informasi dan komunikasi. Bahkan, industri buku mendayagunakan kemajuan teknologi itu untuk menghasilkan buku yang lebih murah, lebih menarik, lebih bermutu, dan menjangkau seluruh lapisan masyarakat. Kemajuan teknologi informasi dan komunikasi telah memungkinkan pula publikasi berbagai informasi dalam bentuk elektronik dengan tampilan media cetak seperti jurnal dan buku. Penggunaan teknologi informasi dan komunikasi dalam industri buku mempengaruhi tata penulisan naskah, penerbitan, pencetakan, pendistribusian, dan perdagangan buku. Buku dalam tampilan elektronik (e-book) dapat terbit dan tersebar mendahului penerbitannya dalam wujud media cetak. Lebih jauh lagi, dengan berkembangnya penerbitan buku elektronik, definisi buku yang selama ini mengacu pada hasil cetak, perlu dikaji kembali dan disesuaikan sehingga mencakup buku elektronik.

Di sisi lain lagi, kemajuan teknologi khususnya di bidang reprografi memberikan dampak negatif pada perkembangan industri perbukuan. Revolusi teknologi reprografi memudahkan pihak-pihak yang tidak bertanggung jawab melakukan pembajakan buku dalam waktu cepat dan jumlah banyak. Pembajakan yang demikian melanggar Undang-Undang Hak Cipta serta merusak tata niaga buku yang merugikan tidak hanya penulis/pengarang/penerjemah, tetapi juga penerbit, toko buku, dan masyarakat pengguna buku. Pembajakan buku juga merugikan Pemerintah, karena pembajak tidak membayar pajak sebagaimana mestinya.

Buku sebagai media cetak atau elektronik dengan berbagai kelebihan yang dimilikinya masih diandalkan untuk menyimpan, menyampaikan, atau menyebarluaskan berbagai jenis informasi berkaitan dengan ilmu pengetahuan, teknologi, seni, agama, serta pembentukan karakter. Buku sebagai sumber informasi utama dicari dan dipergunakan oleh manusia dengan berbagai karakteristik dilihat dari bangsa, suku, ras, agama, golongan, usia, latar belakang pendidikan, profesi, gender, tingkat sosial, dan ekonomi. Bahkan buku menjadi salah satu kebutuhan pokok bagi mereka yang terus belajar sepanjang hayat dan di dalam masyarakat yang gemar membaca dan belajar.

Namun perlu disadari, buku sebagai mana juga media informasi lainnya adalah bebas nilai dalam arti dapat memuat informasi yang positif dan negatif. Positif dalam arti dapat dipergunakan sebagai sumber belajar untuk mengembangkan pengetahuan, kemampuan, dan kepribadian serta dapat juga dijadikan sebagai hiburan. Namun, buku dapat juga diisi dengan informasi yang bersifat negatif sehingga merusak kepribadian dan akhlak, melemahkan keyakinan kepada Tuhan Yang Maha Esa, serta profokatif/agitatif untuk berbuat melawan hukum. Dengan demikian, nilai buku pada khususnya dan bahan bacaan pada umumnya bergantung kepada penulis, pengarang, atau penerjemah, serta kepada pengguna atau pembaca buku itu.

Penting dan strategisnya kedudukan buku sebagai sumber informasi untuk berbagai keperluan mendorong banyak negara berpacu mengembangkan industri buku di negerinya. Amerika Serikat, Inggris, Jepang, Prancis, dan German masih merupakan negara yang mendominasi penerbitan buku. Kemudian, Rusia, Spanyol, Cina, India, Mesir, dan beberapa negara lainnya, terus meningkatkan produksi bukunya tidak hanya untuk kebutuhan di dalam negeri tetapi juga untuk keperluan internasional. Sedemikian giatnya, industri buku di Denmark dan Israel sehingga rasio antara jumlah judul buku yang diterbitkan dan jumlah pendidiknya lebih tinggi daripada di Amerika Serikat, Inggris, dan Perancis. Tingginya produksi buku di sejumlah negara yang disebutkan tadi mengakibatkan pasar buku internasional dikuasai oleh negara-negara tersebut dan negara-negara lain menjadi konsumen dari produksi buku mereka.

Dalam penyelenggaraan pendidikan formal dan nonformal, buku menjadi sumber belajar utama di samping guru. Bahkan di daerah yang kebutuhan akan guru belum terpenuhi atau mutu guru belum seperti yang diharapkan, buku pelajaran menjadi sumber utama dan terutama. Kelangkaan atau ketiadaan buku pelajaran sering menjadi alasan proses dan hasil belajar-membelajarkan tidak memenuhi standar yang diperlukan. Tidak jarang pula terjadi, rendahnya partisipasi anak usia sekolah dan tingginya angka putus sekolah karena ketidakmampuan orangtua/ siswa membeli buku pelajaran. Untuk mengatasi kelangkaan buku pelajaran, beberapa negara seperti Cina dan India membuat buku murah dalam jumlah banyak sehingga kesempatan memperoleh pendidikan semakin merata di negeri itu.

Buku juga berperan dalam meningkatkan mutu pendidikan karena dapat dijadikan sumber informasi mutakhir tentang kemajuan ilmu pengetahuan dan teknologi. Jepang terkenal sangat cepat menerjemahkan buku-buku ilmu pengetahuan dari berbagai negara dan menerbitkannya dalam edisi murah. Filipina sudah lama giat menerbitkan buku-buku ilmu pengetahuan dan teknologi dengan menggunakan kertas yang ekonomis sehingga harganya terjangkau oleh masyarakat. Banyak negara juga menggunakan prinsip "no tax for knowledge" dengan membebaskan 
produksi buku tanpa dikenakan pajak sehingga harga buku menjadi lebih murah.

Selaras dengan kemajuan teknologi informasi dan komunikasi, negara-negara penghasil buku tidak hanya produktif dalam menerbitkan dan menyebarluaskan buku dalam bentuk cetakan, tetapi juga dalam bentuk elektronik serta memperdagangkannya dengan menggunakan jaringan maya (e-commerce). Dengan demikian, bangsa yang kurang memperhatikan pengembangan industri buku di negerinya, akan menjadi pengguna/konsumen produk intelektual bangsa lain dan memiliki ketergantungan serta keterbelakangan dalam mencerdaskan kehidupan bangsanya. Di samping itu, impor buku secara besar-besaran dan berketerusan akan mematikan industri buku dalam negeri sendiri.

Ketersedian buku dilihat dari jumlah, jenis, mutu, serta penyebarannya sangat dipengaruhi oleh keadaan industri buku yang didukung oleh komponen-kompononen utamanya: pencipta gagasan (penulis, pengarang, dan penerjemah), penerbit, percetakan, penyalur (toko buku dan kios buku), serta masyarakat pembaca. Sebagai suatu sistem dalam industri buku, masing-masing komponen itu perlu berinteraksi dan bersinergi sehingga dapat menghasilkan buku yang jumlah dan mutunya sesuai dengan kebutuhan masyarakat penggunanya. Dengan demikian, pengembangan industri perbukuan berkaitan dengan pendidikan, keuangan, perindustrian, perekonomian, perdagangan, transportasi, dan perlindungan konsumen. Keterkaitan dalam lintas sektoral ini menunjukkan, pengembangan industri buku tidak dapat dilakukan secara sektoral atau parsial, tetapi secara sistemik atau holistik dan sistematik. Untuk itu, diperlukan kebijakan atau aturan dalam bentuk perundang-undangan yang secara nasional mengatur hak dan kewajiban masing-masing komponen industri buku.

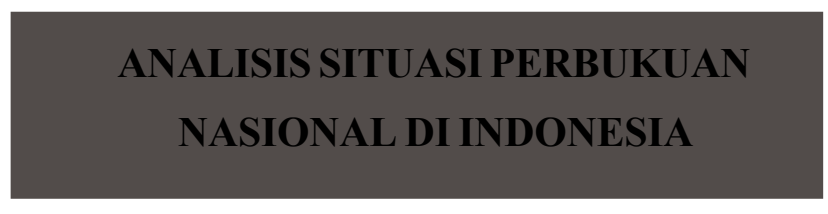

Situasi perbukuan nasional di Indonesia dapat digambarkan dan dianalisis berdasarkan komponenkomponen industri buku yaitu pencipta gagasan, penerbit, percetakan, pendistribusian, dan masyarakat pengguna buku. Akan tetapi, hambatan pertama yang dihadapi dalam memberikan gambaran deskriptif tentang industri buku di Indonesia ialah tidak tersedianya data kuantitatif dan kualitatif yang lengkap, akurat, dan terpercaya karena sampai sekarang ini tidak ada organisasi/lembaga/instansi yang bertugas dan bertanggung jawab dalam pengumpulan serta penyediaan data dan informasi yang lengkap dan berskala nasional tentang masing-masing komponen industri buku. Oleh karena itu, gambaran industri buku berikut ini kurang didukung oleh data yang akurat, lengkap, dan mutakhir.

\section{Pencipta Gagasan}

Pencipta gagasan mencakup penulis, pengarang, dan penerjemah yang mempunyai inisiatif dalam menyusun naskah buku. Komponen ini merupakan penentu jenis, jumlah, dan mutu buku yang diterbitkan, akan tetapi dilihat dari jumlah dan organisasi profesinya, menulis, mengarang, dan menerjemahkan belum merupakan profesi yang menarik dan menjanjikan di Indonesia. Sungguhpun ada organisasi Himpunan Pengarang Indonesia "Aksara", Ikatan Pengarang Indonesia (IPINDO), Wanita Penulis Indonesia (WPI), dan Himpunan Penerjemah Indonesia (HPI), di samping belum menyebar ke seluruh Indonesia, jumlah anggota masing-masing organisasi hanya berkisar antara 70 sampai 120 orang dan beberapa di antaranya merupakan anggota ganda. Di samping itu, anggota organisasi itu pada umumnya memiliki profesi utama lain seperti guru, dosen, peneliti, atau seniman. Kegiatan masing-masing organisasi ini juga jarang kedengaran sehingga keberadaan dan manfaatnya juga kurang terasa bagi anggotanya, masyarakat, dan Pemerintah. Kurangnya jumlah penulis, pengarang, dan penerjemah di Indonesia menyebabkan rendahnya jumlah naskah yang layak diterbitkan.

Keadaan pencipta gagasan seperti yang digambarkan ini antara lain disebabkan: (a) menulis, mengarang, dan menerjemahkan belum menjadi profesi yang dapat diandalkan untuk menjamin kelangsungan hidup yang sejahtera; (b) penulis, pengarang, dan penerjemah tidak selalu memperoleh haknya secara penuh karena diperlakukan tidak jujur oleh penerbit; (c) sungguhpun Undang-Undang tentang Hak Cipta sudah diberlakukan tetapi pembajakan dan plagiat buku belum dapat dihentikan sehingga mengurangi jumlah royalti penulis, pengarang, dan penerjemah; dan (e) di daerah tertentu, penulis, pengarang, dan penerjemah mengalami kesulitan menerbitkan naskahnya karena tidak ada penerbit.

\section{Penerbit}

Jumlah penerbit semakin berkembang setiap tahun akan tetapi penyebarannya masih terkonsentrasi di pulau Jawa dan di kota-kota tertentu, sebagaimana terlihat dalam tabel berikut. 
Berdasarkan data IKAPI (2007) terdapat 729 penerbit di Indonesia dengan sebaran yang tidak merata. Masih ada daerah (Maluku) yang tidak memiliki penerbit. Kebanyakan penerbit berada di pulau Jawa, khususnya di Jakarta, Bandung, Semarang, Surabaya, dan Yogyakarta. Sedangkan jenis buku yang diterbitkan mulai dari yang terbanyak adalah buku umum (32\%), buku sekolah (25\%), buku anak dan remaja (19\%), buku agama (16\%), dan buku perguruan tinggi $(8 \%)$

Jumlah penerbit yang cukup besar itu ternyata tidak menjamin tingginya produksi judul buku baru yang diterbitkan. Menurut IKAPI (2010), jumlah judul buku baru yang diterbitkan rata-rata 12.000 judul termasuk terjemahan dan cetak ulang, yang masih di bawah Malaysia yang sudah mencapai 13.000, apalagi Jepang dan Korea yang sudah mencapai sekitar 100.000 judul. Rendahnya judul buku baru yang diterbitkan terkait dengan rendahnya jumlah naskah yang dihasilkan oleh penulis, pengarang, dan penerjemah.

Tabel 1. Jumlah Penerbit dan Ragam Terbitan

\begin{tabular}{|c|c|c|c|c|c|c|c|c|}
\hline \multirow[b]{2}{*}{ No } & \multirow[b]{2}{*}{$\begin{array}{l}\text { Keanggotaan } \\
\text { IKAPI }\end{array}$} & \multirow[b]{2}{*}{ Propinsi } & \multirow[b]{2}{*}{$\begin{array}{l}\text { Jumlah } \\
\text { Anggota }\end{array}$} & \multicolumn{5}{|c|}{ Terbitan Utama } \\
\hline & & & & Umum & Agama & Perti & Bukpe & \begin{tabular}{|l|} 
Anak/ \\
Remaja
\end{tabular} \\
\hline \multirow{7}{*}{1} & \multirow{7}{*}{ IKAPI DAERAH } & DKI & 300 & 135 & 65 & 73 & 35 & 74 \\
\hline & & Jabar & 164 & 59 & 59 & 34 & 19 & 26 \\
\hline & & Jateng & 103 & 22 & 59 & 18 & 3 & 13 \\
\hline & & DIY & 54 & 30 & 8 & 12 & 7 & 6 \\
\hline & & Jatim & 94 & 39 & 29 & 9 & 6 & 35 \\
\hline & & Sumut & 17 & 9 & 12 & 1 & 1 & 1 \\
\hline & & Sumbar & 6 & 4 & 3 & - & - & 1 \\
\hline \multirow{8}{*}{2} & \multirow{8}{*}{$\begin{array}{l}\text { IKAPI } \\
\text { PERWAKILAN }\end{array}$} & Aceh & 5 & 2 & 2 & - & 1 & 1 \\
\hline & & Riau & 8 & 2 & - & - & 1 & - \\
\hline & & Sumsel & 8 & 3 & 1 & 1 & 4 & - \\
\hline & & Kalbar & 7 & 4 & 2 & - & - & 2 \\
\hline & & Sulsel & 9 & 3 & 1 & - & 2 & 3 \\
\hline & & Bali & 7 & 3 & 2 & 2 & - & - \\
\hline & & NTT & 4 & 1 & 1 & 4 & - & - \\
\hline & & Jambi & 1 & - & 1 & - & - & - \\
\hline \multirow{5}{*}{3} & \multirow{5}{*}{$\begin{array}{l}\text { NON- } \\
\text { KAPIDAERAH/ } \\
\text { PERWAKILAN }\end{array}$} & Lampung & 1 & - & - & - & - & 1 \\
\hline & & Kaltim & 1 & - & 1 & - & - & - \\
\hline & & Kalsel & 1 & 1 & 1 & - & - & - \\
\hline & & NTB & 2 & - & 1 & - & - & - \\
\hline & & Banten & 1 & - & - & - & - & 1 \\
\hline \multirow{2}{*}{\multicolumn{2}{|c|}{$\begin{array}{l}\text { JUMLAH } \\
\text { PERSENTASI }\end{array}$}} & & 793 & 319 & 154 & 79 & 243 & 134 \\
\hline & & & & $32 \%$ & $16 \%$ & $8 \%$ & $25 \%$ & $19 \%$ \\
\hline
\end{tabular}

Sumber: IKAPI, 2007

Dilihat dari modal dan jumlah buku yang diterbitkan, hampir $80 \%$ dari penerbit tergolong pengusaha menengah ke bawah serta tidak memiliki tenaga-tenaga profesional penerbitan yang penuh waktu, seperti editor, ilustrator, dan perancang buku. Untuk mengatasi kekurangan modal itu, penerbit sebenarnya dapat meminjam uang dari bank. Akan tetapi, penerbit mengalami kesulitan dalam memperoleh agunan, apalagi buku hasil produksi mereka tidak dapat dijadikan agunan untuk memperoleh kredit dari bank. Kekurangan modal serta kualitas sumber daya manusia yang dimiliki banyak penerbit memberikan pengaruh yang negatif terhadap mutu isi dan perwajahan buku yang diterbitkan sehingga tidak dapat bersaing di tingkat internasional.

Kurang berkembangnya jumlah dan mutu penerbit di Indonesia antara lain disebabkan: (a) buku belum menjadi kebutuhan pokok bagi kebanyakan masyarakat; (b) harga buku masih relatif mahal karena harga kertas yang tinggi serta pajak ganda yang dikenakan atas produksi dan penjualan buku; (c) di daerah di luar pulau Jawa kebutuhan akan buku belum mendorong pertumbuhan penerbit; (d) buku sebagai hasil produksi tidak dapat dijadikan anggunan oleh penerbit untuk memperoleh kredit dari bank; (e) pembajakan buku belum dapat diberantas secara tuntas; (f) kebijakan Pemerintah di bidang buku sekolah termasuk buku elektronik kurang mendukung pengembangan industri buku karena membatasi pasar penerbit; dan (g) hak-hak intelektual editor, ilustrator, dan perancang buku belum terlindungi secara hukum.

\section{Percetakan}

Jumlah percetakan di Indonesia, termasuk percetakan untuk kartu nama dan undangan tidak kurang dari 7000 yang tersebar di berbagai kota di Indonesia. Sungguhpun jumlah percetakan itu cukup besar akan tetapi hanya sekitar $15 \%$ diantaranya yang memiliki kemampuan untuk mencetak buku. Persatuan Perusahaan Grafika Indonesia (PPGI) mencapai sekitar 2500 percetakan dan di luar itu masih ada sekitar 7000, akan tetapi tidak sampai $20 \%$ di antaranya yang memiliki peralatan yang lengkap untuk mencetak buku. Percetakan-percetakan lain tidak dikembangkan untuk mencetak buku karena jumlah pesanan untuk mencetak buku di kebanyakan daerah, terutama di luar pulau Jawa, tidak menguntungkan percetakan dan ongkos pencetakan lebih murah kalau dilakukan di daerah lain.

Masalah-masalah lain yang dihadapi percetakan ialah (a) harga bahan baku kertas yang tinggi karena Pemerintah kurang mampu mengendalikan dan menekan harga bahan baku kertas; (b) kurangnya pembinaan dan pengawasan terhadap perusahaan percetakan dari instansi yang berwenang sehingga terjadi penyalahgunaan percetakan untuk keperluan yang bersifat negatif seperti untuk pembajakan, pornografi, dan profokasi; (c) perusahaan percetakan untuk buku belum menyebar ke seluruh Indonesia; (d) berkembangnya buku elektronik serta pengunduhannya belum diatur melalui ketentuan hukum mengakibatkan berkurangnya pesanan pencetakan buku; dan (e) 
kurangnya tenaga teknis percetakan yang ahli di bidangnya.

\section{Penyalur/Distributor}

Toko buku, kios buku, dan perpustakaan merupakan ujung tombak dalam penyaluran buku ke pembaca. Semakin banyak toko dan kios buku serta perpustakaan yang tersebar menjangkau seluruh lapisan masyarakat pembaca, semakin mudah memperoleh informasi melalui buku. Ketersediaan dan kemudahan memperoleh buku sebagai sumber belajar meningkatkan mutu, proses, dan hasil belajar di lembaga pendidikan serta memotivasi belajar sepanjang hayat.

Walaupun toko dan kios buku semakin berkembang di Indonesia, tetapi jumlah dan penyebarannya belum memadai dilihat dari jumlah yang membutuhkan buku. Gabungan Toko Buku Indonesia (GATBI) yang merupakan satu-satunya organisasi profesi Toko Buku di Indonesia memiliki anggota tidak sampai 3.500 toko buku. Apabila dihitung kios buku dan toko buku musiman, yang menjual buku hanya pada waktu menjelang dan pada awal tahun ajaran baru, jumlahnya tidak mencapai 5.000. Data ini menunjukkan bahwa toko buku belum menjangkau semua kecamatan yang jumlahnya 5.263 (2004), apalagi desa yang jumlahnya 62.806 (2004). Jumlah dan sebaran toko dan kios buku ini memberikan indikasi kesulitan memperoleh buku di daerah-daerah tertentu.

Untuk memudahkan masyarakat pembaca memperoleh buku, Pemerintah berusaha mengembangkan perpustakan di lembaga-lembaga pendidikan dan perpustakaan umum termasuk perpustakaan keliling serta perpustakaan desa. Melalui program perpustakaan desa dan perpustakaan keliling diharapkan masyarakat desa semakin mudah memperoleh bahan bacaan. Akan tetapi, kelihatannya perpustakaan desa tidak berfungsi seperti diharapkan dan jumlah serta jangkauan dan pelayanan perpustakaan keliling masih jauh dari harapan.

Jumlah dan penyebaran toko buku dan perpustakaan sebagai penyalur bahan bacaan serta jumlah dan jenis bahan bacaan yang disediakan masih sangat kurang dibandingkan dengan kebutuhan masyarakat pembaca dan menyebabkan bahan bacaan terutama buku menjadi langka di desa-desa apalagi di daerah pedalaman. Kelangkaan bahan bacaan ini mengurangi kesempatan bagi masyarakat untuk belajar sepanjang hayat. Keadaan yang demikian dapat juga mengakibatkan mereka yang sudah melek aksara menjadi buta aksara kembali karena kemampuan membaca mereka tidak dikembangkan.

Masalah-masalah yang dihadapi dalam penyaluran buku antara lain ialah (a) toko dan kios buku serta perpustakaan belum menyebar menjangkau semua lapisan masyarakat khususnya di pedesaan dan daerah terpencil; (b) toko dan kios buku tidak dapat berfungsi sepenuhnya sebagai penyalur buku sepanjang waktu karena perdagangan buku bersifat musiman yang ramai hanya menjelang dan awal tahun pelajaran; (c) domisili penerbit yang terkonsentrasi di wilayah tertentu membuat biaya penyaluran buku ke lokasi yang jauh dari domisili penerbit menjadi tinggi sehingga menyebabkan harga buku menjadi mahal dan tidak terjangkau kebanyakan masyarakat di pedesaan; (d) peranan toko buku sebagai ujung tombak dalam penyaluran buku melemah akibat (1) adanya kecenderungan penerbit langsung memasarkan bukunya ke lembaga-lembaga pendidikan, (2) semakin maraknya pemesanan langsung buku ke penerbit di dalam dan luar negeri, dan (3) kemudahan memperoleh buku melalui dunia maya/internet; toko dan kios buku serta perpustakaan belum dapat memenuhi kebutuhan semua masyarakat pembaca, karena keterbatasan jumlah dan jenis buku yang tersedia; (e) pengelolaan toko dan kios buku serta perpustakaan masih belum dapat memenuhi kebutuhan dan keinginan masyarakat pembaca; (f) toko dan kios buku tertentu menjual buku bajakan, karena kurangnya pengawasan; (g) anak di bawah umur dapat dengan mudah dan bebas membaca dan membeli buku untuk orang dewasa di toko buku, karena buku belum dikategorikan berdasarkan tingkat usia pembacanya; dan (h) belum ada peraturan perundang-undangan mengatur tata niaga buku.

\section{Masyarakat Pembaca}

Pada sensus 2010 ditemukan bahwa terdapat 234.181.000 jiwa penduduk Indonesia dan tinggal $7,42 \%$ saja yang berusia 15 tahun ke atas masih buta aksara. Jumlah penduduk Indonesia yang sudah mampu membaca dan menulis sangat besar. Mereka yang sudah melek aksara tentu memerlukan bahan bacaan termasuk buku. Apalagi kalau semua masyarakat yang sudah melek huruf itu menyadari pentingnya belajar sepanjang hayat dengan menggunakan buku sebagai salah satu sumber belajar maka kebutuhan akan buku sangat besar.

Akan tetapi ternyata kegemaran membaca dan belajar masih tergolong rendah di Indonesia. Berdasarkan data Unicef minat baca masyarakat Indonesia menempati urutan 52 di Asia Timur dan budaya lisan masih dominan dibandingkan dengan budaya baca dan tulis. Dengan demikian, sungguhpun jumlah calon konsumen buku sangat besar akan tetapi buku belum menjadi kebutuhan pokok masyarakat. Kebutuhan akan buku baru sangat terasa di kalangan lembaga pendidikan. 
Sistem pembelajaran di lembaga pendidikan juga belum berhasil membentuk budaya baca di kalangan peserta didik dan pendidik/tenaga kependidikan. Dalam perhitungan Programme for International Student Assessment (PISA) tahun 2009, Indonesia menempati posisi ke 58 dari 66 negara yang diukur tingkat kemampuan siswa dalam membaca, matematika dan ilmu pengetahuan alam. Kemampuan membaca yang rendah merupakan indikasi minat dan kegemaran membaca di kalangan peserta didik dan pendidik di Indonesia juga masih rendah.

Untuk meningkatkan minat baca, Pemerintah telah melakukan berbagai gerakan yang bersifat monumental seperti penetapan bulan Mei sebagai Bulan Buku Nasional, Bulan September sebagai Bulan Gemar Membaca dan Hari Kunjung Perpustakaan, serta Gerakan Wakaf Buku dalam Bulan Desember. Melalui pendidikan nonformal dikembangkan pula Taman Bacaan Masyarakat mengarah pada pusat sumber belajar masyarakat. Akan tetapi, upaya-upaya mewujudkan masyarakat gemar membaca dan belajar masih perlu ditingkatkan secara terpadu sehingga berbagai hambatan yang ada dapat diatasi.

Dari berbagai kajian tentang masyarakat pembaca dapat dirumuskan sejumlah masalah berikut (a) kegemaran dan kebiasaan membaca masyarakat masih rendah dan buku belum menjadi kebutuhan pokok masyarakat; (b) kemudahan memperoleh informasi melalui media audio visual mengurangi minat masyarakat untuk membaca buku; (c) daya beli masyarakat belum cukup kuat untuk menjangkau harga buku yang dianggap relatif mahal. (d) masyarakat belum sepenuhnya berperan serta memberantas pembajakan termasuk mengkopi buku; (e) budaya lisan masih sangat kuat dan kebiasaan menyampaikan serta memperoleh informasi secara tertulis belum menjadi kebiasaan bagi kebanyakan orang; (f) sistem pembelajaran di lembaga-lembaga pendidikan kurang mampu mewujudkan kebiasaan dan kegemaran membaca di kalangan peserta didik; (g) kondisi sosial ekonomi sebagian besar masyarakat belum mendukung minat dan kegemaran membaca; dan (h) masyarakat pedesaan masih mengalami kesulitan memperoleh buku.

\section{Pembinaan Perbukuan}

Pemerintah menyadari bahwa buku merupakan sumber informasi dan sarana pendidikan dalam mencerdaskan bangsa, oleh karena itu, industri buku dengan komponen-komponennya perlu dikembangkan. Melihat kompleksnya masalah industri buku dan menyangkut berbagai dan lintas sektor seperti pendidikan, perindustrian, perdagangan, dan keuangan, maka melalui Keppres No 5 Tahun 1978, Pemerintah membentuk Badan Pertimbangan dan Pengembangan Buku Nasional (BPPBN) yang bertugas melakukan berbagai kajian dan merumuskan konsep-konsep kebijakan di bidang perbukuan nasional. Badan ini pulalah yang melakukan kajian perbukuan secara nasional dan mengidentifikasi perlunya UndangUndang untuk mengatur perbukuan secara nasional. Tahun 1997, BPPBN menyusun draf awal UU tentang perbukuan nasional tetapi tidak ditindaklanjuti sampai Badan ini dibubarkan. BPPBN dirasakan kurang fungsional dalam mengatasi berbagai masalah serta lebih berfokus pada kajian-kajian dan rekomendasi kebijakan serta tidak melakukan kegiatan operasional, maka tahun 1999 sesuai dengan salah satu rekomendasi hasil Kongres Perbukuan Nasional tahun 1995, dibentuk Dewan Buku Nasional (DBN) yang diketuai oleh Presiden RI dengan sejumlah Menteri dan wakil masyarakat perbukuan sebagai anggotanya. Akan tetapi, DBN tersebut tidak dapat berfungsi seperti yang diharapkan karena anggotaanggotanya memiliki tugas pokok utama lain. Sejak dibentuk tidak pernah terlihat hasil nyata dari DBN ini serta pembinaan dan pengembangan perbukuan nasional semakin tidak jelas. Oleh karena itu, belakangan ini ada rencana untuk membubarkan DBN ini.

Untuk membina perbukuan di lingkungan pendidikan dan kebudayaan, melalui Keppres No. 4 Tahun 1987 dibentuk Pusat Perbukuan di lingkungan Departemen Pendidikan dan Kebudayaan. Di samping berfungsi untuk mengembangkan buku-buku untuk keperluan pendidikan, Pusat ini juga berupaya berperan serta mendorong perkembangan industri buku nasional dengan melakukan berbagai seminar dan pelatihan yang berkaitan dengan perbukuan, pemasyarakatan minat dan gemar membaca, serta melanjutkan upaya melahirkan Undang-Undang tentang Sistem Perbukuan Nasional. Akan tetapi dengan alasan reformasi birokrasi, Pusat Perbukuan ini diintegrasikan dengan Pusat Kurikulum menjadi Pusat Kurikulum dan Perbukuan dengan lingkup tugas dan fungsi yang semakin sempit.

Uraian di atas menunjukkan bahwa lembagalembaga yang dibentuk untuk membina dan mengembangkan industri buku di Indonesia tidak efektif serta tidak efisien. Namun dengan reformasi birokrasi yang dilakukan belakangan ini semakin tidak jelas lagi lembaga yang bertugas dan bertanggung jawab dalam membina dan mengembangkan industri buku di Indonesia. 


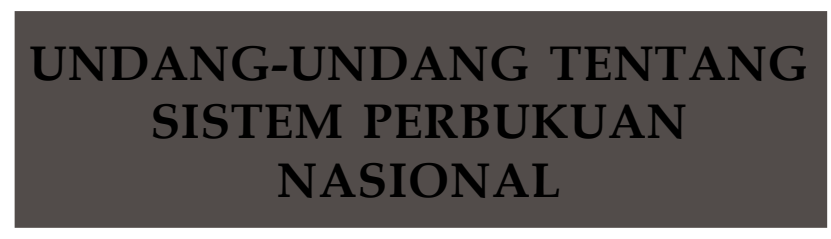

Gambaran dan analisis situasi perbukuan nasional yang sudah dipaparkan menunjukkan kecenderungan melemahnya industri buku nasional di Indonesia dan dapat diprediksi bahwa dalam era globalisasi ini, industri buku nasional tidak akan mampu bersaing dengan industri buku di negara lain

Jumlah penduduk Indonesia yang besar akan menjadi pasar yang menjanjikan bagi industri buku asing serta masyarakat Indonesia akan menjadi konsumen buku-buku asing. Melalui buku-buku asing itu berbagai nilai asing akan juga masuk ke Indonesia serta dapat merusak karakter bangsa, tatanan nilai budaya, serta jati diri bangsa Indonesia secara perlahan tetapi pasti.

Untuk mengatasi itu, industri buku di Indonesia perlu dikembangkan dan diperkuat dengan memberikan perlindungan hukum melalui undang-undang yang mendorong pertumbuhan pencipta gagasan (penulis, pengarang, dan penerjemah), penerbit, percetakan, penyalur, dan masyarakat pembaca. Oleh karena komponen-komponen industri buku itu saling terkait dan tergantung satu sama lain dalam membentuk masyarakat membaca dan belajar sepanjang hayat, maka peraturan perundang-undangan itu perlu disusun dalam pola pikir industri buku sebagai suatu sistem perbukuan.

Sistem perbukuan nasional diharapakan dapat: (a) membangun dan memperkokoh industri buku nasional sehingga mampu berkembang, berkolaborasi, dan bersaing di tingkat wilayah dan internasional; (b) mengatur tata kelola perbukuan yang menghasilkan buku bermutu yang mampu mencerdaskan dan membangun integritas kehidupan bangsa; (c) memperkuat rasa cinta tanah air dan terbangunnya karakter bangsa; (d) memberikan kemudahan akses kepada masyarakat untuk memperoleh buku; (e) menumbuhkan budaya minat baca masyarakat; (f) mewujudkan tata kelola perbukuan yang sehat, kuat, dinamis, berkualitas, memiliki daya saing, dan terpadu; (g) meningkatkan jumlah dan mutu sumber daya perbukuan; (h) meningkatkan jumlah dan mutu buku yang diterbitkan sesuai dengan kebutuhan masyarakat Indonesia; (i) meningkatkan ketersediaan dan pendistribusian buku secara merata dengan harga yang terjangkau oleh semua lapisan masyarakat; (j) meningkatkan pemanfaatan buku sebagai sumber belajar dan sarana memperluas wawasan pengetahuan; dan (k) meningkatkan martabat bangsa melalui industri perbukuan tingkat lokal dan nasional.

Dengan tujuan yang demikian maka UU tentang Sisbuknas diharapakan dapat: (a) memperjelas pengertian istilah-istilah yang dipergunakan dalam sistem perbukuan; (b) mengatur hak dan kewajiban pihak-pihak yang terkait dalam sistem perbukuan nasional; (c) mengatur tata kelola penulisan dan penerjemahan naskah; (d) mengatur tata kelola pencetakan buku; (e) mengatur tata kelola penerbitan buku; (f) mengatur tata kelola penyaluran buku; (g) mengatur tata kelola pemanfaatan buku; (h)mengatur pembinaan perbukuan nasional; (i) mengatur penghargaan kepada pihak-pihak yang berjasa dalam pengembangan industri perbukuan nasioanal; serta (j) mengatur pemberian sanksi bagi pihak-pihak yang melanggar ketentuan dalam industri perbukuan nasional.

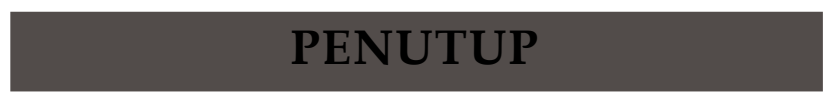

Keberhasilan mencapai tujuan mencerdaskan kehidupan bangsa sebagai salah satu tujuan Proklamasi Kemerdekaan Negara Kesatuan Republik Indonesia sangat tergantung pada keberhasilan sistem pendidikan nasional mewujudkan masyarakat terdidik yang gemar membaca dan gemar belajar sepanjang hayat serta tidak hanya terbatas di lingkungan lembaga pendidikan tetapi berlangsung di mana pun dan kapan pun sesuai dengan kemampuan masingmasing individu. Dalam proses belajar itu diperlukan aneka sumber belajar yang salah satunya adalah bahan bacaan pada umumnya dan buku pada khususnya,

Untuk menghasilkan buku dalam jumlah, jenis, dan mutu yang dapat meningkatkan kemampuan intelektual, emosional, dan spiritual, diperlukan industri buku yang sehat, tangguh, maju, mampu berkolaborasi dan bersaing serta mampu menyediakan buku yang dibutuhkan masyarakat secara nasional.

Industri buku didukung oleh sejumlah komponen yang saling terkait dan tergantung satu sama lain dalam suatu sistem yang perlu dikembangkan dan dilindungi dengan undang-undang dan ketentuan yang bersifat nasional. Rancangan Undang-Undang tentang Sistem Perbukuan Nasional yang sudah dirintis oleh Badan Pertimbangan dan Pengembangan Perbukuan Nasional (BPPBN) sejak tahun 1997 perlu segera disempurnakan dan ditindaklanjuti melalui prosedur dan mekanisme yang berlaku sehingga dalam 
waktu tidak terlalu lama lagi Indonesia telah memiliki Undang-Undang tentang Sistem Perbukuan Nasional.

\section{DAFTAR PUSTAKA}

Altabach, P.A. \& Teferra, A, (Eds). (1998). Publishing development: A book of readings. Chestnutt Hill MA: Bellagio Publishing Network.

Departemen Pendidikan dan Kebudayaan, (1995). Kongres perbukuan nasional I. Jakarta: Departemen Pendidikan dan Kebudayaan

Komisi X DPR RI, (2011). Naskah akademik rancangan undang-undang Republik Indonesia tentang sistem perbukuan nasional
Sitepu, B.P. (2006), Penyusunan buku pelajaran, Jakarta: Verbum Publishing

Undang-Undang Dasar Negara Republik IndonesiaTahun 1945

Undang-Undang Republik Indonesia N0 20 Tahun 2003 tentang Sistem Pendidikan Nasional

http//:www.ikapi.org

\section{KETERANGAN PENULIS}

Bintang Petrus Sitepu, saat ini bertugas sebagai guru besar di jurusan Teknologi Pendidikan Fakultas Ilmu Pendidikan Universitas Negeri Jakarta 